\title{
Bioequivalence Study of Two 10 mg Montelukast Immediate-Release Tablets Formulations: A Randomized, Single-Dose, Open-Label, Two Periods, Crossover Study
}

\author{
Enrique Muñoz*, Daniel Horacio Ocampo, Edgar Emilio Espinal and Natalia Yépes
}

CECIF (Centro de la ciencia y la investigación farmacéutica), Medellín, Colombia

\begin{abstract}
A bioequivalence study was developed to compare the bioavailability of two formulations of Montelukast 10 mg tablets in twenty-four healthy volunteers. The Test product was Montelukast manufactured by Tecnoquímicas S.A. (Jamundí - Colombia) and the Reference product was Singulair ${ }^{\circledR}$ (Montelukast) made by Merck Sharp \& Dohme Ltd. (Northumberland - United Kingdom). A crossover design $2 \times 2$ of single-dose, with two treatments, two periods, two sequences and with a washout period of one week was used. Blood samples were collected from 0,5 to 24 hours after dosing. The determination of Montelukast in plasma was performed using a previously validated bio-analytical method of high-performance liquid chromatography with fluorescence detector (HPLC-FLD). Through Montelukast concentration curves versus time measured in the volunteers' plasma, the pharmacokinetic parameters and bioequivalence were determined for both products. The pharmacokinetic parameters determined in this study for both the reference and test products were $C_{\max } 440.6 \pm 227.4 \mathrm{ng} / \mathrm{ml}, 460.5 \pm 170.9 \mathrm{ng} / \mathrm{ml}, \mathrm{AUC}_{0 \rightarrow \infty} 3196.5 \pm 1546.8$ ng/h.ml, $3284.9 \pm 1270.0$ ng/h.ml and AUC ${ }_{02} 3162.5 \pm 1537.6$ ng/h.ml, $3251.6 \pm 1221.8$ ng/h.ml respectively. For Montelukast, with a confidence interval of $90 \%$, the ratio of the logarithmic transformation test product / reference product for $\mathrm{AUC}_{0 \rightarrow \infty}$ was from 94.5 to 110.9 and the ratio test product/reference product for $\mathrm{C}_{\max }$ was from 89.0 to 110.4. These intervals are within the established bioequivalence range and therefore determined that the test formulation is interchangeable or bioequivalent to the reference.
\end{abstract}

Keywords: Montelukast; Bioequivalence; Pharmacokinetics; Highresolution Liquid chromatography; Spectrophotometry; Fluorescence

\section{Introduction}

Montelukast sodium is a hygroscopic; optically active; photolabile; white-colored (or whitish) powder with the following chemical formula: $\mathrm{C}_{35} \mathrm{H}_{35} \mathrm{ClNNaO}_{3} \mathrm{~S}[1,2]$ (Figure 1). It is a potent; orally active compound with anti-inflammatory properties that significantly improves asthmatic inflammation parameters. It binds with great affinity and

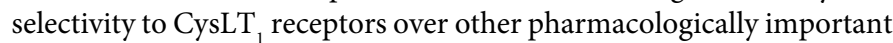
receptors of the respiratory tract; such as the prostanoid; cholinergic; or $\beta$-adrenergic receptors. Montelukast potently inhibits physiological actions of $\mathrm{LTC}_{4} ; \mathrm{LTD}_{4} ; \mathrm{LTE}_{4}$ leukotrienes at CysLT $\mathrm{L}_{1}$ receptors without any agonist activity [3-5]. Therefore; it is indicated for the prophylaxis and chronic treatment of asthma in adults and 12-month-old or older pediatric patients; and it helps to control the symptoms of seasonal and perennial allergic rhinitis [3].

Montelukast is rapidly absorbed following oral administration; reaching peak plasma concentration of approximately $500 \mathrm{ng} / \mathrm{ml}$ between 3 to 4 hours after administering a $10 \mathrm{mg}$ tablet to adults in fasted state. The average oral bioavailability is $64 \%$ and is not modified by a standard meal, in addition, the $\mathrm{C}_{\max }$ remains unaffected. Over $99 \%$ of Montelukast binds to plasma proteins is extensively metabolized in to undetectable metabolites when plasma concentrations are at steady state. The average plasma clearance of Montelukast in healthy adults is $45 \mathrm{ml} / \mathrm{min}$ and it is almost exclusively by biliary route. [3-5]. A halflife between 3.5 and 5.0 hours has been reported for a $10 \mathrm{mg}$ tablet of Montelukast [6-10].

The objective of this study was to establish the Bioequivalence of two Montelukast formulations; comparing the Bioavailability of a single dose of Montelukast $10 \mathrm{mg}$ tablets produced by Tecnoquímicas S.A. (Test Product) to a single dose of Singulair $10 \mathrm{mg}$ tablets produced by Merck Sharp \& Dohme Ltd. (Reference Product)

\section{Product analysis}

For the test product; Montelukast $10 \mathrm{mg}$ immediate-release coated tablets; batches 2J2389A; 2R3789A and 2E1775 were used. These were produced by Tecnoquímicas S.A (Jamundí - Colombia). For the reference product; Singulair ${ }^{\circledR} 10 \mathrm{mg}$ immediate-release coated tablets; batch H011579 was used; it was produced by Merck Sharp \& Dohme<smiles>CC(C)(O)c1ccccc1CCC(SCC1(CC(N)=O)CC1)c1cccc(/C=C/c2ccc3ccc(Cl)cc3n2)c1</smiles>

Figure 1: Sodium Montelukast. [R-(E)]-1-[[[1-[3-[2-(7-chloro-2-quinolinyl) ethenyl]phenyl]-3-[2-(1-hydroxy-1-methylethyl)phenyl]propyl]thio]methyl] cyclopropaneacetic acid; monosodium salt. Taken from DrugBank [6].

*Corresponding author: Enrique Muñoz Carnago, CECIF (Centro de la Ciencia y la Investigación Farmacéutica), Medellín, Antioquia, Colombia Tel: 57-4-3778584 ext. 107/104; Fax: 57-4-3778584 ext. 102; E-mail: estudiosbiofarmaceuticos@cecif.org

Received May 02, 2014; Accepted May 25, 2014; Published May 31, 2014

Citation: Muñoz E, Ocampo DH, Espinal EE, Yépes N (2014) Bioequivalence Study of Two $10 \mathrm{mg}$ Montelukast Immediate-Release Tablets Formulations: A Randomized, Single-Dose, Open-Label, Two Periods, Crossover Study. J Bioequiv Availab 6: 086-090. doi:10.4172/jbb.1000186

Copyright: ( 2014 Muñoz E, et al. This is an open-access article distributed under the terms of the Creative Commons Attribution License, which permits unrestricted use, distribution, and reproduction in any medium, provided the original author and source are credited. 
Citation: Muñoz E, Ocampo DH, Espinal EE, Yépes N (2014) Bioequivalence Study of Two $10 \mathrm{mg}$ Montelukast Immediate-Release Tablets Formulations: A Randomized, Single-Dose, Open-Label, Two Periods, Crossover Study. J Bioequiv Availab 6: 086-090. doi:10.4172/ jbb.1000186

Ltd. (Northumberland - United Kingdom). All pharmaceuticals were obtained from pharmacies in the city of Medellín; Colombia.

Prior to the Bioequivalence study development; both products were compared regarding pharmaceutical forms; labeling; patient information leaflet and tablet description. The assessment of the active ingredient identity, the active ingredient content, the uniformity of dosage units, the dissolution test and dissolution profiles in four different media were also performed using analytical methods, based on a monograph from the British pharmacopeia; proposed for publishing in 2014; and the FDA guidelines [11,12]; all of this in order to determine the pharmaceutical equivalence of the Test and Reference products.

Products would be accepted as pharmaceutical bioequivalents and appropriate for the bioequivalence study, if, the retention time of Montelukast (test sample) and the standard (reference) by active ingredient identity analysis is identital; if, the \% assay and content uniformity of the products show 95.0 and $105.0 \%$ of the declared amount; if, in dissolution testing, the dissolved percentage of the product is not less than $80 \%$ in $20 \mathrm{~min}$; if, the dissolution profile values of f1 "point-to-point differences" between 0 and 15 and f2"similarity factor" between 50 and 100, besides coefficients of variation for dissolved Montelukast with a maximum of $20 \%$ on the first time point (mention minutes here) and under $10 \%$ for the remaining time points (mention minutes) $[11,12]$.

\section{Subjects and Methods}

\section{Subjects}

Volunteers were enrolled through open announcement made by the CECIF in different universities throughout the region; and through online announcement in the website: www.cecifcolombia. org and through informative talks about the study. Subjects were healthy Colombians of both genders; aged between 18 and 55 years old. Subjects had a weight difference limit of $15 \%$ according to their height and a body mass index between 20 and $25 \mathrm{Kg} / \mathrm{m}^{2}$ [13].

Subject's inclusion in the study was assessed for those volunteers with no history of liver; heart; kidney; central nervous system or respiratory disease. Normal blood pressure (for adults; systolic pressure must be under $120-130 \mathrm{mmHg}$ and $80-90 \mathrm{mmHg}$ for diastolic pressure); appropriate heart rate (normal resting rate is between 60 and 100 pulsations per minute) and normal spirometry. Normal results based on performed clinical exams (complete blood count; fasting blood glucose; aminotransferase analysis; full cholesterol panel test; serum creatinine; serum triglycerides; HIV test; serum albumin; urine cytochemistry) and a negative pregnancy test for female volunteers.

Volunteers were informed about the study nature and a written consent form was obtained from each subject. They were asked not to take any medication; enzymatic inductors and even contraceptives for at least two weeks prior to the first sample collection period [14-16]; to avoid the intake of food or beverages containing xanthine; chocolates; tea; coffee and cola based beverages; and not to consume alcoholic beverages and cigarettes 48 hours before the dose administration. Volunteers had a 12 hour fasting before administering the Montelukast $10 \mathrm{mg}$ tablet and were allowed to have breakfast only after 2 and a half hours after dose administration.

\section{Study design}

Study protocol and consent form were approved by the Bioethics Committee of Universidad de Antioquia's Research Headquarters CBE-
SIU in Medellin; Colombia; which is regulated by resolution 008430 from October $4^{\text {th }}$; 1993 from the Colombian Ministry of Health; which establishes the technical; scientific and management regulations for health research and complies with guidelines of resolution 002378 from June $25^{\text {th }} ; 2008$ from the Ministry of Health and Social Protection; which establishes the Good Clinical Practices for institutions conducting drug research with human subjects. It also adjusts to the principles of the World Medical Association presented in the Declaration of Helsinki (1964); last review in 2013 and the Code of Federal Regulations; title 45; part 46; regarding the protection of human subjects; from the United States Department of Health \& Human Services of the National Institutes of Health (June 18 ${ }^{\text {th }} ; 1991$ ) [17-20].

This was a crossover $2 \times 2$ randomized; single-dosed; two treatments; two periods; two sequences; with an appropriate oneweek washout period study. Each subject was randomly assigned to a treatment sequence and all subjects took both the Montelukast Test Product and the Reference Product.

\section{Drug administration}

For samples collection; volunteers were gathered for more than 12 hours in a space that belongs to the Corporation for Health Studies; CES Clinic (Medellín - Colombia). They were subjected to identical housing environments such as food intake; liquid volume intake; physical activity; lying position; among others. One hour before dose administration; an IV catheter was introduced to each volunteer and a target blood sample was collected. The dose was administered orally with $240 \mathrm{~mL}$ of water.

\section{Sampling}

Blood samples were collected from each volunteer's antecubital vein using test tubes with anticoagulant (Heparin sodium); according to the following timepoints: $0 ; 0.5 ; 1 ; 1.5 ; 2 ; 2.5 ; 3 ; 3.5 ; 4 ; 6 ; 8 ; 12$ and 24 hours. In an approximate time range of $20 \mathrm{~min}$ after collecting the samples; the tubes were centrifuged at $3500 \mathrm{rpm}$ to obtain blood plasma; which was stored in covered sterile tubes in order to provide ultraviolet protection given the high photosensitivity of Montelukast; and they were dropped immediately to $-20^{\circ} \mathrm{C}$ until analysis $[21,22]$.

During both study periods; volunteers were under medical care with constant vital signs monitoring to prevent or counteract any adverse reaction.

\section{Plasma samples analyses}

Plasma concentrations of Montelukast were measured through a bio-analytical method using High-Performance Liquid Chromatography (HPLC) previously validated by the CECIF following the established guidance from international analytic method validation guidelines to demonstrate an adequate sensitivity; specificity; linearity; accuracy and precision [23-25].

Extraction conditions of Montelukast from plasma and chromatographic conditions for its quantification were determined during the prior review of what is reported on literature; making the required modifications to optimize the process $[7,8,10,21,26-28]$.

Samples preparation was made through protein precipitation with acetonitrile and their analysis was made by using a Liquid Chromatographer with Fluorescence Detection (FLD). For this case; a Shimadzu UFLC-NEXERA system was used. Data acquisition was performed using LabSolutions 2008-2010 software by Shimadzu Corporation. Analyte separation was achieved with a Zorbax Eclipse 
Citation: Muñoz E, Ocampo DH, Espinal EE, Yépes N (2014) Bioequivalence Study of Two $10 \mathrm{mg}$ Montelukast Immediate-Release Tablets Formulations: A Randomized, Single-Dose, Open-Label, Two Periods, Crossover Study. J Bioequiv Availab 6: 086-090. doi:10.4172/ jbb.1000186

XDB-C18 $4.6 \mathrm{~mm}$ ID $\times 150 \mathrm{~mm}(5 \mu \mathrm{m})$ chromatographic column at $40^{\circ} \mathrm{C}$. An isocratic elution with a mobile phase composed by acetonitrile: trihydrate sodium acetate buffer $25 \mathrm{mM}$ at $\mathrm{pH}=4.0 ; 75: 25$; with a constant flow of $1 \mathrm{ml} / \mathrm{min}$ was done. Total runtime was $10 \mathrm{~min}$. Montelukast was monitored at an emission wavelength of $350 \mathrm{~nm}$ and a $390 \mathrm{~nm}$ excitation wavelength; and $25 \mu$ l were injected into the HPLC.

\section{Pharmacokinetic parameters analysis}

Montelukast plasma levels for each of the volunteers in each timepoint were tabulated and according to this data; Montelukast plasma concentration vs. time curves were drawn for both formulations. Pharmacokinetic parameters compared in this Bioequivalence singledose study for both formulations are as follows: $\mathrm{C}_{\max }$ and $\mathrm{T}_{\max }$ which correspond to the curve peak; $\mathrm{AUC}_{0-24}$ calculated with the trapezoidal rule; area under the curve since the last sampling timepoint $(\mathrm{t})$ to infinity $\left(\mathrm{AUC}_{24-\infty}\right)$ determined through equation $\mathrm{AUC}_{\mathrm{t}-\infty}=\mathrm{C}_{24} / \mathrm{K}_{\mathrm{e}}$; $\mathrm{AUC}_{0-\infty} ;$ ergo; $\mathrm{AUC}_{0-\infty}=\mathrm{AUC}_{0-24}+\mathrm{AUC}_{24-\infty} . \mathrm{K}_{\mathrm{e}}$ was found out from the slope in the curve's final elimination phase; as was $\mathrm{t}_{1 / 2}$.

The statistical method used to determine the Bioequivalence between both formulations was based on the procedure known as two one-sided test; to determine if transformed average values of pharmacokinetic parameters measured after administering both the test and reference products are comparable [29].

For the statistical analysis of data derived from this in vivo study; general parametric procedures for linear models (normal theory) were used and an analysis of variance (ANOVA) was performed using the statistical application Phoenix ${ }^{\mathrm{TM}}$ Winnonlin; version 6.3; 2013; based on the pharmacokinetic parameters $\mathrm{C}_{\max }$ and $\ln \mathrm{AUC}_{0-\infty}$; keeping the average concentration profiles of volunteers grouped in categories. Some sources of variation such as cycles and treatments were also included, as established by the FDA bioequivalence division [30].

It was concluded that both formulations are bioequivalents, if the $\mathrm{AUC}_{0-\infty}$ and $\mathrm{C}_{\max }$ ratio between the test and reference products with a CI of $90 \%$ is within the bioequivalence range established by the FDA (from 80 to 125) [30,32-34].

\section{Results}

\section{Products analysis}

Comparison of pharmacologicalforms, labeling, patientinformation leaflet and the tablets did not show any significant difference between two products. The active ingredient identity analysis showed identical retention time of Montelukast for the standard in mobile phase, for the four samples prepared from the reference drug batch and for the three batches of test drug, proving the identity of Montelukast. Analytic results of the active ingredient content; uniformity of dosage units and dissolution test are summarized in Table 1; showing compliance with specifications $[11,12]$. Regarding the dissolution profiles, a similar behavior between the reference drug and the test drug were observed. They showed minor point-to-point difference and profile similarity, complying with difference and similarity factors $\mathrm{f} 1 \mathrm{y} f 2$.

\section{Subjects}

For the study; selected subjects were healthy Colombians of both genders; aged between 18 and 30 years old. Average weight and height were $62.70 \pm 10.15 \mathrm{~kg}$ and $1.68 \pm 0.07 \mathrm{~m}$ respectively. No severe adverse event that inhibited the participation of any of the subjects was observed during the conduction of the study.

Two female volunteers did not show up for the study due to personal issues; so two male volunteers were retired to keep pair sequences and complete statistical treatment; without affecting the final result after having performed the corresponding randomization test. Thus; the study was performed on twenty subjects.

\section{Bio-analytic method validation}

The method was selective, during the analysis of six target plasma samples from different sources, plus a hemolyzed sample and a lipid sample, no interferences were found between the analyte and matrix's endogenous components. Calibration curve for Montelukast in plasma showed linearity in a concentration range from 10 to $1000 \mathrm{ng} / \mathrm{ml}$ with a correlation coefficient of 1.0. Detection limit for the study was $1.1 \mathrm{ng} /$ $\mathrm{ml}$ and quantification limit was $1.9 \mathrm{ng} / \mathrm{ml}$. Accuracy expressed in intraday coefficients of variation was $1.1 \% ; 1.7 \%$ and $1.6 \%$ for $50 \mathrm{ng} / \mathrm{ml} ; 250$ $\mathrm{ng} / \mathrm{ml}$ and $750 \mathrm{ng} / \mathrm{ml}$ respectively; and inter-day coefficient was $2.9 \%$; $1.0 \%$ and $1.0 \%$ for $50 \mathrm{ng} / \mathrm{ml} ; 250 \mathrm{ng} / \mathrm{ml}$ and $750 \mathrm{ng} / \mathrm{ml}$ respectively. As for the method's retrieval; $87.9 \%$; $94.7 \%$ and $97.5 \%$ were obtained for $50 \mathrm{ng} / \mathrm{ml} ; 250 \mathrm{ng} / \mathrm{ml}$ and $750 \mathrm{ng} / \mathrm{ml}$ respectively. Montelukast proved its stability against the different conditions proposed by the FDA [24].

\section{Pharmacokinetic and statistical analysis}

The average of the pharmacokinetic profiles and Montelukast concentration in plasma vs. time for all 20 volunteers is shown on Figure 2; and the average pharmacokinetic parameters are described in Table 2 .

ANOVA results showed there are no significant statistical differences regarding the following variables: cycles and treatment in terms of $\mathrm{C}_{\max }$ and $\mathrm{AUC}_{0-\infty}$.

With a CI of $90 \%$, the average of the $\mathrm{C}_{\max }$ and $\mathrm{AUC}_{0-\infty}$ ratio between the test and reference products for all 20 volunteers is shown on Table 3.

\section{Discussion}

Twenty volunteers completed the study; none of them showed adverse reactions. Sample size was chosen following the Instituto Nacional de Vigilancia de Medicamentos y Alimentos (INVIMA)

\begin{tabular}{|c|c|c|c|}
\hline PRODUCT & Active Ingredient Content \%ODV & Uniformity of Dosage Units \%ODV & Dissolution Test Average Dissolved \% in 20 min \\
\hline Reference H011579 & $98.56 \pm 0.02$ & 95.12 & 96.10 \\
\hline Trial 2R3789A & $104.23 \pm 0.05$ & 104.13 & 96.40 \\
\hline Trial 2E1775 & $103.16 \pm 0.02$ & 102.94 & 97.60 \\
\hline Trial 2J2389A & $103.85 \pm 0.06$ & 104.50 & 96.40 \\
\hline Specification & \%ODV: $95-105 \%$ & \%ODV: $95-105 \%$ & $\begin{array}{c}\text { Average Dissolved \% in 20 min should not be under } 80 \% \\
\text { of the declared amount }\end{array}$ \\
\hline Result & Complies & Complies & Complies \\
\hline
\end{tabular}

\%ODV: Percentage over declared value

Table 1: Results obtained from the active ingredient content controls; uniformity of dosage units and dissolution test for the reference drug batch and the test drug batches. 
Citation: Muñoz E, Ocampo DH, Espinal EE, Yépes N (2014) Bioequivalence Study of Two $10 \mathrm{mg}$ Montelukast Immediate-Release Tablets Formulations: A Randomized, Single-Dose, Open-Label, Two Periods, Crossover Study. J Bioequiv Availab 6: 086-090. doi:10.4172/ jbb.1000186

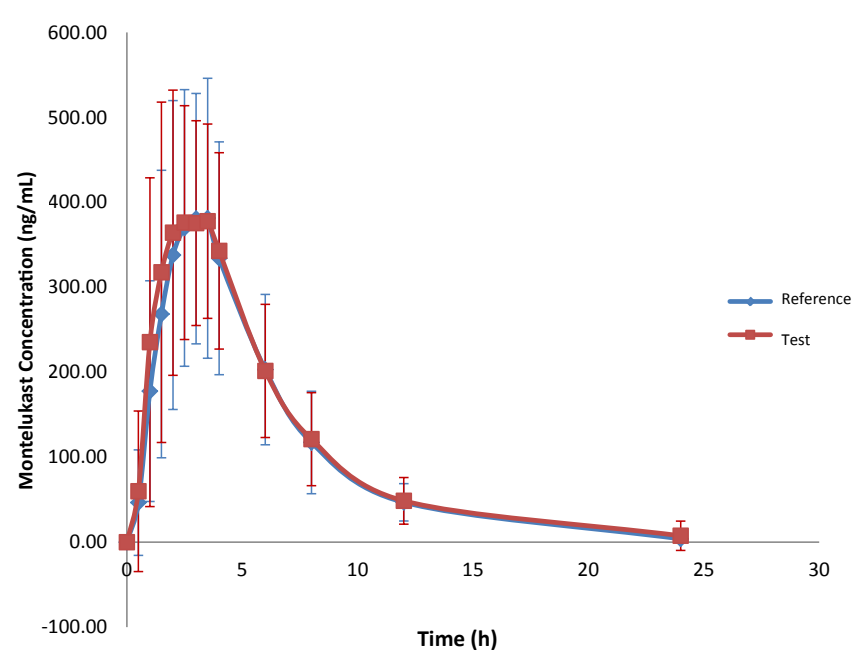

Figure 2: Average of pharmacokinetic profiles of Montelukast plasma concentration vs. time from 0 to 24 hours for 20 volunteers after a singledose administration of the test product and the reference product $(10 \mathrm{mg}$ Montelukast tablets)

\begin{tabular}{|c|c|c|}
\hline \multirow{2}{*}{ Parameters } & \multicolumn{2}{|c|}{ Mean \pm DS } \\
\hline & Test Product & Reference Product \\
\hline$T \max (h)$ & $2.5 \pm 1.5$ & $3 ; 0 \pm 2 ; 0$ \\
\hline$C \max (\mathrm{ng} / \mathrm{ml})$ & $460.5 \pm 170.9$ & $440.6 \pm 227.4$ \\
\hline$A U C_{0 \rightarrow 24}$ (ng/h.ml) & $3251.6 \pm 1221.8$ & $3162.5 \pm 1537.6$ \\
\hline$A U C_{0 \rightarrow \infty}$ (ng/h.ml) & $3284.9 \pm 1270.0$ & $3196.5 \pm 1546.8$ \\
\hline $\operatorname{Ke}(1 / h)$ & $0.204 \pm 0.144$ & $0.203 \pm 0.163$ \\
\hline$t_{1 / 2}(h)$ & $3.4 \pm 1.6$ & $3.4 \pm 1.4$ \\
\hline
\end{tabular}

Table 2: Average of the pharmacokinetic parameters of Montelukast tablets after a $10 \mathrm{mg}$ single-dose administration of the Test and Reference products to 20 volunteers.

\begin{tabular}{|c|c|c|}
\hline Parameter & $\begin{array}{c}\text { Ratio Test Product/Reference } \\
\text { Product }\end{array}$ & Cl 90\% \\
\hline $\mathbf{C}_{\max }$ (ng/ml) & 99.7 & $89.0-110.4$ \\
\hline InAUC $_{0 \rightarrow \infty}$ (ng.h/ml) & 102.4 & $94.5-110.9$ \\
\hline
\end{tabular}

Table 3: Confidence Intervals of $90 \%$ and average of the ratio $C_{\max }$ and $I n A U C_{0}$ between the Test product and the Reference products of $10 \mathrm{mg}$ Montelukast tablets.

guidelines; which suggest a minimum of 12 individuals; and other bibliographic sources suggest that real sample size should never be less than 12 volunteers $[14,16,31]$. Thus; participation of twenty volunteers was appropriate for the study.

A bio-analytic method for Montelukast quantification in plasma through HPLC-FLD was validated; which proved to be effective; specific; precise and exact for the operating range; obtaining results that comply with the acceptance criteria established in international guidelines. On the other hand; it was made clear that Montelukast was stable in plasma during sample processing at room temperature for 8 hours; in storage at $-20^{\circ} \mathrm{C}$; during freezing-thawing cycles and in the autosampler after sample processing; complying with FDA specifications; which emphasize that coefficients of variation and percent errors must be fewer than $20 \%$.

Bioequivalence study between $10 \mathrm{mg}$ Montelukast tablets produced by Tecnoquímicas S.A. (Test Product) and Singulair $10 \mathrm{mg}$ produced by Merck Sharp \& Dohme Ltd. (Reference Product); was successfully carried out in 20 healthy volunteers; who received a single-dose of each study formulation; allowing the comparison between the obtained pharmacokinetic parameters values with the ones published in scientific articles related to pharmacokinetics; and/or bioavailability of this drug; observing similar behaviors to those found in the parameters from the area under the curve; maximum concentration; time to maximum concentration; half-life; Table $2[21,22]$.

As for the bioequivalence of both formulations, Table 3 shows, for a CI of $90 \%$, that the ratio between the test and reference products of $\mathrm{C}_{\max }$ and $\mathrm{AUC}_{0-\infty}$ falls within the bioequivalence range of 80 to 125 established by the FDA [30]. Therefore; it can be concluded that the test formulation (10 mg Montelukast coated tablets) produced by Tecnoquímicas S.A.; is interchangeable or bioequivalent to the reference formulation (Singulair ${ }^{\otimes} 10 \mathrm{mg}$ coated tablets) produced by Merck Sharp \& Dohme Ltd.

\section{Acknowledgements}

This study was sponsored by TECNOQUÍMICAS S.A.

We thank the investigators group from the medical division at Tecnoquímicas S.A. for enabling the development of this project; which is required to register the product before the INVIMA or any other Regulatory Agencies.

Let this be the record that there are no conflicting interests neither between the two institutions nor their investigators.

\section{References}

1. DrugBank (2012) Montelukast sodium. Merck \& Co. Inc. Whitehouse Station NJ 08889. USA.

2. http://www.lookchem.com/Product_30698/CasNo_151767-02-1/Montelukastsodium.html

3. Merck (2012) Singulair Montelukast sodium; The Patient Product Information for Singulair. Merck Sharp \& Dohme Corp.

4. Merck (2012) Singulair Montelukast sodium; The Prescribing Information for Singulair. Merck Sharp \& Dohme Corp.

5. http://www.medicamentosplm.com/productos/singulair_comprimidos masticables.htm

6. Sripalakit P, Kongthong B, Saraphanchotiwitthaya A (2008) A simple bioanalytical assay for determination of montelukast in human plasma: Application to a pharmacokinetic study. J Chromatogr B 869: 38-44.

7. Amin RD, Cheng H, Rogers JD (1995) Determination of MK-0476 in human plasma by liquid chromatography. J Pharm Biomed Anal 13: 155-158.

8. Liu L, Cheng H, Zhao JJ, Rogers JD (1997) Determination of montelukas (MK-0476) and its S-enantiomer in human plasma by stereoselective highperformance liquid chromatography with column-switching. J Pharm Biomed Anal 15: 631-638.

9. Challa BR, Awen BZ, Chandu BR, Khagga M, Kotthapalli CB (2010) Method Development and Validation of Montelukast in Human Plasma by HPLC Coupled with ESI-MS/MS: Application to a Bioequivalence Study. Sci Pharm 78: 411-422.

10. Shafaati A; Zarghi A; Foroutan SM; Khoddam A; Madadian B (2010) Rapid and Sensitive Determination Of Montelukast in Human Plasma by High Performance Liquid Chromatographic Method Using Monolithic Column: Application to Pharmacokinetic Studies. J Bioequiv Availab 2: 135-138.

11. British Pharmacopoeia (2014) Draft monograph subject to change. Montelukast tablets.

12. Food and Drug Administration (1997) Guidance for Industry. Dissolution Testing of Immediate Release Solid Oral Dosage Forms.

13. Metropolitan Life Insurance Company (1983) Statistical bulletin documenta geigy tablas científicas.

14. INVIMA (2001) Guía de Biodisponibilidad y Bioequivalencia de medicamentos Acta 51 de 1997; Resolución 1400 de 2001. INVIMA; Colombia.

15. Schoors DF, De Smet M, Reiss T, Margolskee D, Cheng H, et al. (1995) Single dose pharmacokinetics; safety and tolerability of MK-0476; a new leukotriene $\mathrm{D}_{4}$-receptor antagonist; in healthy volunteers. Br J Clin Pharmacol 40: 277-280. 
Citation: Muñoz E, Ocampo DH, Espinal EE, Yépes N (2014) Bioequivalence Study of Two $10 \mathrm{mg}$ Montelukast Immediate-Release Tablets Formulations: A Randomized, Single-Dose, Open-Label, Two Periods, Crossover Study. J Bioequiv Availab 6: 086-090. doi:10.4172/ jbb.1000186

16. Food and Drug Administration (2003) Guidance for industry. Bioavailability and bioequivalence studies for orally administered drug products.

17. Ministerio de Salud (1993) Normas científicas, técnicas y administrativas para la investigación en salud. Resolución №08430. Ministerio de Salud; Bogotá - Colombia.

18. Ministerio de protección social (2008) Resolución No 2378. Ministerio de protección social; Bogotá - Colombia.

19. Brazil; $59^{\text {th }}$ World Medical Association (2013) Declaration of Helsinki: Ethical principles for medical research involving human subjects. Fortaleza - Brazil.

20. Departamento de salubridad y servicios humanos; Institutos nacionales de salud y Oficina para la protección de riesgos de investigación (1991) Código de reglamentos federales; título 45; Bienestar Social. Sección 46; protección de sujetos humanos. Junio 18 de 1991. Estados Unidos.

21. Al-Rawithi S, Al-Gazlan S, Al-Ahmadi W, Alshowaier IA, Yusuf A, et al. (2001) Expedient liquid chromatographic method with fluorescence detection for montelukast sodium in micro-samples of plasma. J Chromatogr B 754:527-531.

22. Al Omari MM, Zoubi RM, Hasan El, Khader TZ, Badwan AA (2007) Effect of light and heat on the stability of montelukast in solution and in its solid state. $J$ Pharm Biomed Anal 45:465-471.

23. ICH Q2A (1995) Text on Validation of Analytical Procedures: definitions and terminology.

24. Food and Drug Administration (2001) Guidance for industry. Bioanalytical Method Validation.

25. Cartula MC, Celma C, Encíma G, Jansat JM, Nieto C, et al. (2001) Métodos en Bioanálisis, Asociación Española de Farmacéuticos de la Industria, validación de Métodos Analíticos. Barcelona, España.
26. Kitchen CJ, Wang AQ, Musson DG, Yang AY, Fisher AL (2003) A semiautomated 96-well protein precipitation method for the determination of montelukast in human plasma using high performance liquid chromatography/ fluorescence detection. J Pharm Biomed Anal 31: 647-654.

27. Chauhan B, Rani S, NivsarkarM , Padh H (2006) A new liquid-liquid extraction method for determination of montelukast in small volume human plasma samples using HPLC with fluorescence detector. Indian J Pharm Sci 68: 517520 .

28. Alsarra I, Khalil NY, Sultan M, Al-Ashban R, Belal F (2005) Spectrofluorometric determination of montelukast in dosage forms and spiked human plasma. Pharmazie 60: 823-826.

29. Myers W, Myers RE (1991) Probabilidad y Estadística, Cuarta edición, editorial McGraw-Hill.

30. Food and Drug Administration (2001) Guidance for industry. Statistical approaches to establishing bioequivalence.

31. Estévez FE (2000) Estudios de bioequivalencia: Enfoque metodológico y aplicaciones prácticas en la evaluación de medicamentos genéricos. Rev Med Uruguay 16: 133-143.

32. Gibaldi M, Perrier M (1982) Pharmacokinetics. $2^{\text {nd }}$ Edition. Marcel Dekker Press. New York.

33. Rowland M, Tozer T (1997) Clinical Pharmacokinetics, concepts and applications. $3^{\text {rd }}$ Edition. Lea and Febiger Press.

34. Wagner JG (1993) Pharmacokinetics for the Pharmaceutical Scientist. Technomic Publishing Co Press. 